\title{
導電紙による電気防食系の電位/電流分布の推定*
}

\author{
望月紀保**, 白水 司***, 平塚征一**** \\ **中川防蝕工業株式会社開発部 \\ ***中川防蝕工業株式会社技術研究所 \\ ****中川防蝕工業株式会社腐食検查室
}

\section{Estimation of Potential/Current Distribution in a Cathodic Protection System by Electroconductive Paper Method*}

\author{
Noriyasu Mochizuki**, Tsukasa Shirouzu*** and Seiichi Hiratsuka**** \\ ** Research and Development Department, Nakagawa Corrosion \\ Protecting Co., Ltd. \\ ***Technical Laboratory, Nakagawa Corrosion Protecting Co., Ltd. \\ ****Corrosion Inspection Unit, Nakagawa Corrosion Protecting \\ Co., Ltd.
}

\begin{abstract}
Theoretical analyses of potential/current distribution in cathodic protection system with complex boundary conditions have rarely been discussed in detail because of the difficulty of mathematical treatment. By electroconductive paper method, despite the limited application to 2-dimensional, Laplace equation solution can be derived, since the boundary conditions can be represented graphically on electroconductive papers. By using this, potential/current distribution with complex boundary conditions can be estimated relatively easily. The application of the electroconductive paper method to the actual system have been demonstrated for the application of cathodic protection of steel piles in seawater and internal surface of stainless steel tank for hot water reservoir. A fairly good agreement was observed between the measured values and those obtained by electroconductive paper method which indicates the effectiveness of the electroconductive paper method for the estimation of potential/current distribution.
\end{abstract}

\section{1. 緒言}

電気防食において電位/電流分布を正確に把握するこ とは，有効な電気防食を行う上で重要なことである。

一般的には, 防食対象物となるカソード表面の電位分 布が一次分布になるような方法は，防食効果及び経済的 見地からも行わないことが原則となって招り，淡水や土 中などの高抵抗率環境では, 塗装等の被覆材と電気防食 の併用が行われている。

* 1983 年 9 月第 10 回コロージョンセミナーで一部発 表 (於 箱根・静雲荘)

****** $=101$ 東京都千代田区神田鍛治町 2-2-2 (22-2 Kanda Kajicho, Chiyoda-ku, Tokyo, 101 Japan)

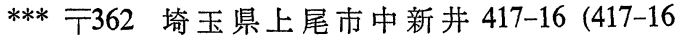
Nakaarai, Ageo, Saitama, 362 Japan)
これまで電気防食における電位/電流分布に関しては, Kasper $^{1)}$, Hoar $^{2)}$, Nelson $^{3)}$ など，種々の研究報告はあ るが，いずれる単純な系に和ける分布を問題にしている ため，境界条件が複雑な実環境とは余り対応が得られな いといわれている。

実際面に执いては，現場に护ける仮通電試験によっ て電位分布の把握や電極配置が決められているが，仮通 電試験の行いにくい土中や送水管内面の電位/電流分布 については，それぞれ Pritula 式)や Morgan 式占によ って推定されることもある。

導電紙到による電位/電流分布の推定は，二次元では あるものの, 境界条件が複雑な系についても比較的容易 にラプラス方程式の解が得られるため，電気防食設計上 への適用は非常に有効であると考兄られる。 
本稿は，電気防食系に批ける電位分布の推定を導電紙 を用いて行ったところ，実測データと導電紙結果との間 に比較的良好な対応が得られたので報告するるのであ る。

\section{2. 導電紙による測定}

本実験で取り扱う電気防食系に対し，次のような仮定 を打く。

(1) 環境は均質溶液である

(2) 電極の分極特性を，直線分極とする

(3) 金属電極内部には，電位差はない

上述の条件設定によって，対象となる電気防食系を適 当な断面で切断するなどの方法によって問題を二次元に 置きかえることができるならば，導電紙を用いての電 位/電流分布の解析が可能となる。

導電紙によって電位/電流分布を求めるには，境界条 件が対象となる系と同一になるように導電紙上に設定す ればよい。

電気防食系においては，多くの場合，カソードは二次 電位/電流分布（以下，二次分布之呼ぶ）となる。

二次分布に和ける境界条件の設定では，一次電位/電 流分布 (以下，一次分布と呼ぶ) 飞適用される, (1) 相似, (2) 対称, (3) 互換, (4) 切断, 合成, の 4 則に加 兄て, 電極表面上での境界条件が加わる。4 則の詳細な説明

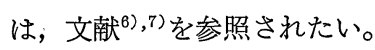

二次分布に 4 則が適用できる理由は, 解析上は二次分 布を問題にしている場合でも，導電紙上での電位/電流 分布はあくまで一次分布であるためである。

一方，電極表面上での境界条件については，電気防食 系に対して次式が成立する。

$$
\phi_{a}{ }^{\mathrm{s}}-\phi_{\mathrm{c}}{ }^{\mathrm{s}}=V_{\mathrm{ex}}-E_{a}{ }^{0}+E_{\mathrm{c}}{ }^{0}-h_{a} i_{a}-h_{\mathrm{c}} i_{\mathrm{c}}
$$

ここで $\phi^{\mathrm{s}}$ : 溶液電位 $V_{\mathrm{ex}}$ : 極間電圧

$E^{0}:$ 自然電位 $h:$ 分極抵抗

$i$ : 電流密度

下付添字は，a：アノード，c：カソードを表す。

実環境に和ける電極に対して完全な直線分極の適用が 不可能な場合, 電位/電流分布の解析上は, 実際の対象 系に抢いて問題とされる電位あるいは電流密度領域が （1）式を満足するような直線近似を行ら必要がある。こ の時 $E^{0}$ は, 直線分極適用上での自然電位となる。

分極パラメータ $L(h / \rho, \rho:$ 溶液抵抗率 $)$ を用いて

$$
\begin{aligned}
& \phi_{a}{ }^{\mathrm{s}}=V_{\mathrm{ex}}-E_{a}{ }^{0}+E_{\mathrm{c}}{ }^{0}-i_{a} \rho L_{a} \\
& \phi_{\mathrm{c}}{ }^{\mathrm{s}}=i_{\mathrm{c}} \rho L_{\mathrm{c}}
\end{aligned}
$$

と特くと，(2)，(3) 式を満足する境界条件を導電紙上に 設定すればよいことになる。

一例を挙げる。

Fig. $1(a)$ に示す二次元の電気防食モデルがある。系

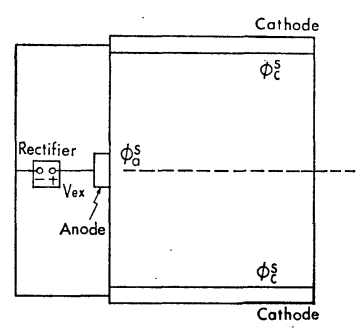

(a)

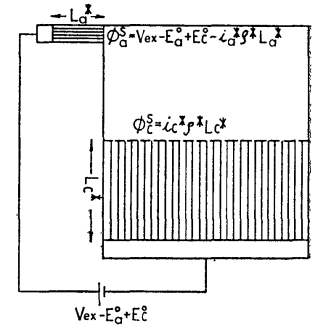

(b)
Fig. 1 2-dimensional representation of a cathodic protection system.

(a) 2-dimensional cathodic protection model

(b) Representation of model ( $a$ ) on a electroconductive paper

の対称性から対称則および切断・合成則を適用し，かつ (2)，(3) 式に示す境界条件を満たすためには，Fig. 1 (b) のように導電紙上に表せばよい。

ここで, 実環境に护る $\rho, L, i$ 亿対して，導電紙上 に和けるとれらの值を上付添字*をつけてそれぞれ $\rho^{*}$, $i^{*}, L^{*}$ として示した。

導電紙上に表した電極表面の境界条件の意味は, 電流 の流れを電極面に対して垂直方向に規制した微小幅のス リットを設けることによって $i \rho L$ を表し，内部に電位 差のない金属電極を導電ペイントを塗って表示したとこ ろにある。

更に，両電極間に $V_{\mathrm{ex}}-E_{a}{ }^{0}+E_{\mathrm{c}}{ }^{0}$ の電圧を印加する ことによって (2)，(3) 式は完全に満足され, スリット 両端間の電位差を測定することによって電極 各 部の電 位/電流分布は求めることがでさる。しかしながら $V_{\mathrm{ex}}$ $-E_{a}{ }^{0}+E_{\mathrm{c}}{ }^{0}$ が非常に高電圧の場合には，一般に測定上 便利な電圧 $V_{\mathrm{ex}}$ *を印加した時の電位差を測定し， $\left(V_{\mathrm{ex}}\right.$ $\left.-E_{a}{ }^{0}+E_{\mathrm{c}}{ }^{0}\right) / V_{\mathrm{ex}} *$ の比に応じた補正を行うという方法を とる。

本実験では, 得られたデータに対してカソード各位置 の電位/電流密度は, 次式から求めた。

$$
\begin{aligned}
& E_{\mathrm{cj}}=E_{\mathrm{c}}{ }^{0}-\Delta E_{\mathrm{cj}} \cdot\left(V_{\mathrm{ex}}-E_{a}{ }^{0}+E_{\mathrm{c}}{ }^{0}\right) / V_{\mathrm{ex}} * \\
& i_{\mathrm{cj}}=\Delta E_{\mathrm{cj}} \cdot\left(V_{\mathrm{ex}}-E_{a}{ }^{0}+E_{\mathrm{c}}{ }^{0}\right) / \rho / L_{\mathrm{c}} / V_{\mathrm{ex}} *
\end{aligned}
$$

$$
\text { ここで }
$$

$E_{\mathrm{cj}}: \mathrm{j}$ 番目のスリットに対応する実環境での電位

$i_{\mathrm{cj} j}$ ： $\mathrm{j}$ 番目のスリットに対応する害環境での電流密 度

$\Delta E_{\mathrm{cj}}: \mathrm{j}$ 番目のスリット両端の電位差

$V_{\mathrm{ex}}{ }^{*}$ : 導電紙上での印加電圧

更に，電気防食系に和いてはアノード形状がカソード 形状に比べて非常に小さいため, アノードの形状そのも のが導電紙上に表現しにくいこと以外に，アノードの分 極パラメータ $L_{a}$ までる無視されがちになりやすい。 
本実験では次のように対処した。

アノード表面の電位分布は均質であると仮定すると, 導電紙上でのアノード分極パラメータ内の抵抗 $R_{1}$ は次 式で求まる。

$$
R_{1}=\rho^{*} \cdot L_{a}^{*} / S^{*}
$$

$S^{*}:$ 導電紙上に括けるアノードの外周 導電紙解析に执いて考えるべき全抵抗を $R$ としたとき， 全抵抗に占める $R_{1}$ の割合を (7) 式により求める。

$$
\alpha=R_{1} / R
$$

$\alpha<0.01$ の場合， $L_{a}$ は無視することにした。

なお，微小アノード形状の導電紙上への表示について は実例の中で説明することにする。

本実験に抢いて, 測定に用いた導電紙は, 巴川製紙 (株) 製「アナコンペーパー」, 導電ペイントは藤倉化成 (株)の「ドータイト，D 550」である。

\section{3. 導電紙の電気防食系への適用例}

\section{1 海洋構造物への Al 陽極の取り付け間隔}

Fig. 2 は, 鋼矢板に対して $200 \times 230 \times 1500 \mathrm{~mm}$ の Al 陽極で電気防食を行っている場合の水平方向の断面 図である。

鋼矢板の形状は， 1 枚 $40 \mathrm{~cm}$ の長さの鋼矢板を模擬 したもので, 細部にわたる形状までは考慮していない。

鋼矢板を電気防食するために必要な水平方向の陽極間 隔 $l$ を, 導電紙を用いて検討した。

電極表面の境界条件として通電初期を想定し，アノー ド，カソードについてそれぞれ Fig. 3, Fig. 4 に示す 直線分極を適用した。海水の抵抗率を $25 \Omega \mathrm{cm}$ とする と, 分極パラメータは $L_{a}=0.4 \mathrm{~cm}, L_{\mathrm{c}}=400 \mathrm{~cm}$ とな る。また，無限遠の境界条件として，鋼矢板の凸部から

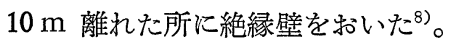

系の対称性から，上記条件を $1 / 50$ 縮尺で導電紙上に 表すと Fig. 5 のよらになる。

$L_{a}$ の取り扱いについては, 導電紙上の極間抵抗を $R_{2}$ とすると， $R_{2}=1,015 \Omega$, 抵抗率 $\rho^{*}=430 \Omega$ であるとこ

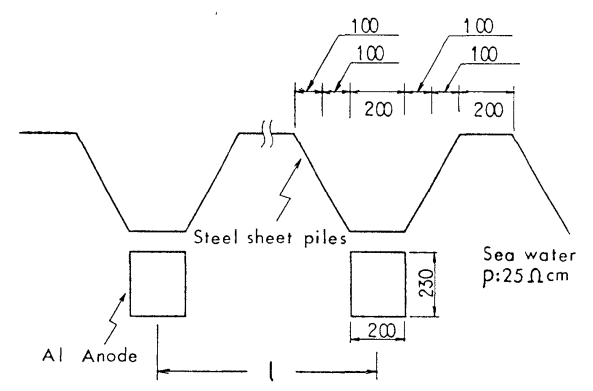

Fig. 2 Cathodic protection model for steel sheet piles.

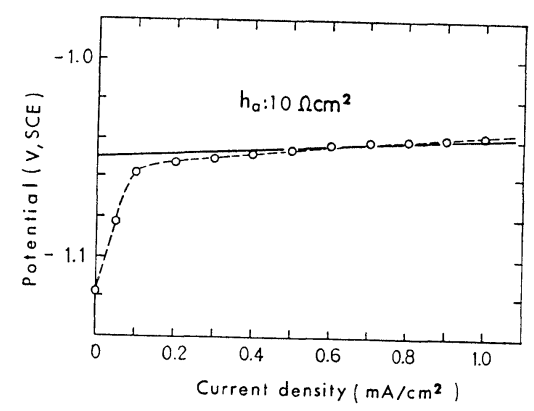

Fig. 3 Anodic polarization curve of $\mathrm{Al}$ anode in seawater.

$\mathrm{h}_{a}$ : Anodic polarization resistance.

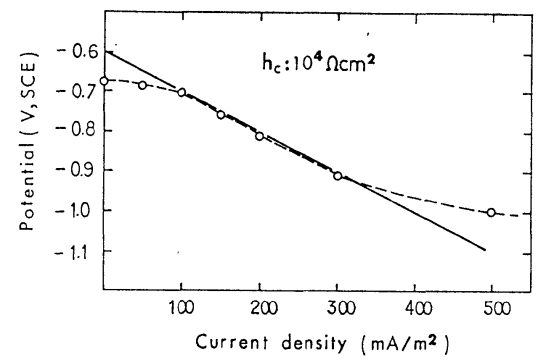

Fig. 4 Cathodic polarization curve of mild steel in seawater.

$\mathrm{h}_{\mathrm{c}}$ : Cathodic polarization resistance.

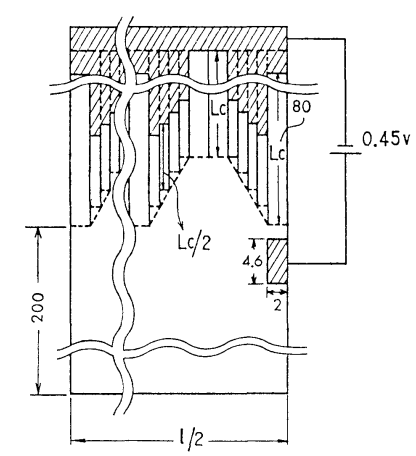

Fig. 5 Representation of the cathodic protection model shown in Fig. 2 on a electroconductive paper.

ろから (6)，(7)式より $\alpha$ (本系の場合, $\left.R=R_{1}+R_{2}\right)$ を 求めると $0.004(<0.01)$ となるため， $L_{a}$ は無視するこ とにした。

分極パラメータの設定では, カソード表面に凸凹があ るため, 斜線部については, 鋼矢板の幾何学的形状か ら, 水平方向の分極パラメータに対しスリットの幅と長 さを半分にした長方形をあてはめた。

境界条件より，一定電圧として $0.45 \mathrm{~V}\left(E_{\mathrm{c}}{ }^{0}-E_{a}{ }^{0}\right)$ を 印加し，得られたデータに対し（4）式を用いて各 $l$ に 


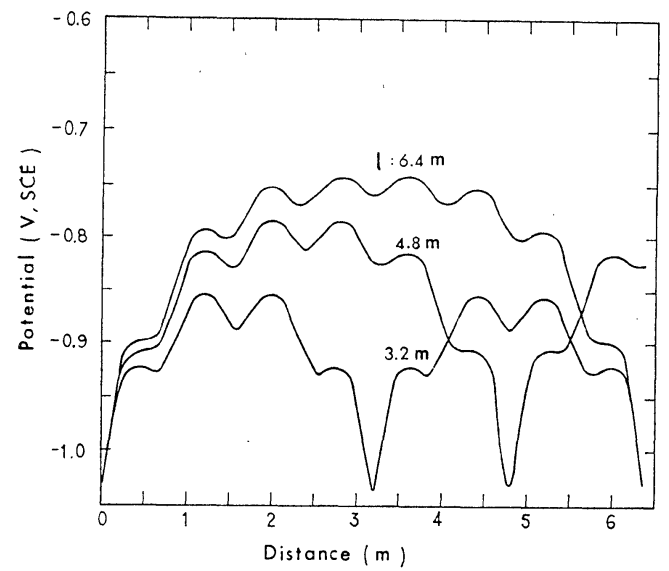

Fig. 6 Effect of anode interval ( $l$ in Fig. 2) on the potential distribution of steel sheet piles determined by electroconductive paper method.

Cathodic protection model is given in Fig. 2.

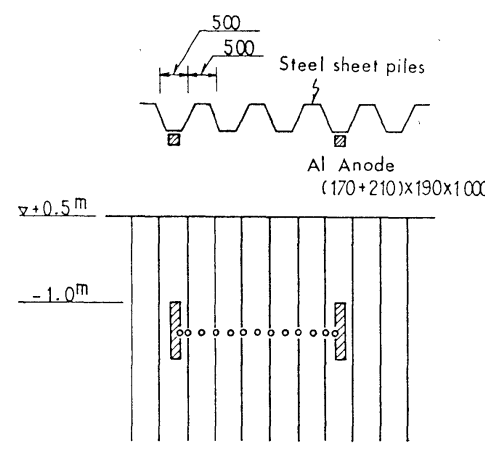

0 : Points of potential measurement

Fig. 7 Potential distribution measured on steel sheet piles in natural seawater environment.

抢ける電位分布カーブを描くと Fig. 6 のようになる。

Fig. 6 の結果は, 防食電位の上限を $-0.8 \mathrm{~V}$ (SCE) とすると, $40 \mathrm{~cm}$ 鋼矢板の場合, 陽極間隔は, $3.2 \mathrm{~m}$ ピ ッチで取り付ける必要があることを示している。これ は, 現在, 電気防食施工で行われている取り付け間隔9 と非常によく一致するもので, 導電紙による推定に大き な誤差はなかったものと考学ることができる。

実環境に和注電位分布との対応例を次に示す。

対象は, 電気防食施工後 10 年経過した岸壁の鋼矢板 で，形状及び陽極の取り付け間隔は Fig. 7 亿示す通り である。電位測定は, ダイバーによって，陽極間を水平 方向に $25 \mathrm{~cm}$ ピッチで行われた。結果をFig. 8 に 一・ーで示す。

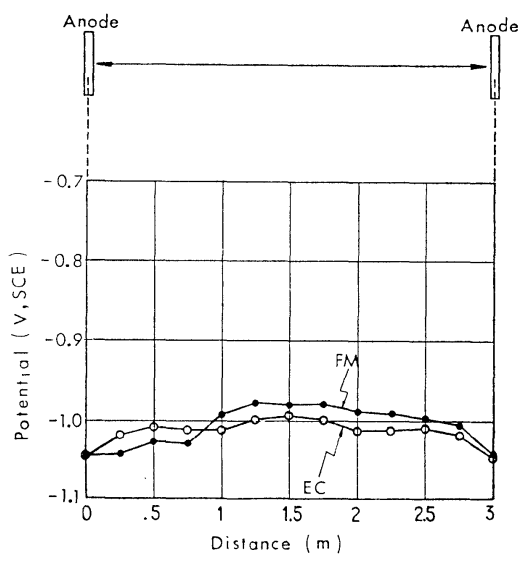

Fig. 8 Comparison of results of field measurement (FM) and those by electroconductive paper method (EC). Cathodic protection system is given in Fig. 7.

一方，導電紙に上る解析は，現場に和汀る陽極，鋼矢 板の分極特性が把握できなかったため, 電極表面におけ る境界条件の設定では，陽極については先の検討之同 様, $E_{a}{ }^{0}=-1.05 \mathrm{~V}$ (SCE), $h_{a}=10 \Omega \mathrm{cm}^{2}\left(L_{a}=0.4 \mathrm{~cm}\right)$, 鋼矢板については $E_{\mathrm{c}}{ }^{0}=-0.6 \mathrm{~V}(\mathrm{SCE})$ とし, $h_{\mathrm{c}}$ は, 現場に和ける取り付け陽極 1 個当りの発生電流が $0.3 \sim$ $0.5 \mathrm{~A}$ の範囲で計測されたとの結果をもとに, 陽極 1 個 当りの発生電流が $0.4 \mathrm{~A}$ 程度に相当する $h_{\mathrm{c}}$ として $5 \times 10^{4} \Omega \cdot \mathrm{cm}^{2}\left(L_{\mathrm{c}}=2.0 \times 10^{3} \mathrm{~cm}\right)$ を用いた。結果を Fig. 8 にー○一で示す。ちなみに, このとき導電紙上 から導き出される陽極 1 個当りの発生電流は $0.405 \mathrm{~A}$ である。

Fig. 8 の結果は, 実測値と導電紙結果との間に比較 的良好な対応が得られているとみることができ, 導電紙 による電位分布解析の有効性が示された。

\section{2 ステンレス製温水タンク内面側壁の電位/電流分} 布

$1.5 \mathrm{~m} \phi$ の円筒状ステンレス (SUS 304) 製温水タンク がある。このタンク内面は, タンク側壁に沿って, 垂直 方向に等間隔に張った 6 本の $1.5 \mathrm{~mm} \phi$ の $\mathrm{Pt}$ めっき $\mathrm{Ti}(\mathrm{Pt}-\mathrm{Ti})$ 線をアノードとして, 定電圧の電気防食を 行っている。温水は, 温度 $60^{\circ} \mathrm{C}$, 抵抗率 $2,000 \Omega \cdot \mathrm{cm}$ の水道水で, 電極配置はタンク水平方向断 面で示すと Fig. 9 のようになっている。

本タンクに括ける 側壁の電位/電流分布の推定を導電 紙を用いて行い, 電位分布については, 実測值との対応 を調べた。

電極表面の境界条件として，アノード，カソードそれ ぞれ Fig. 10, Fig. 11 に示す直線分極を適用した。各 パラメータを示すと Table 1 のようになる。 


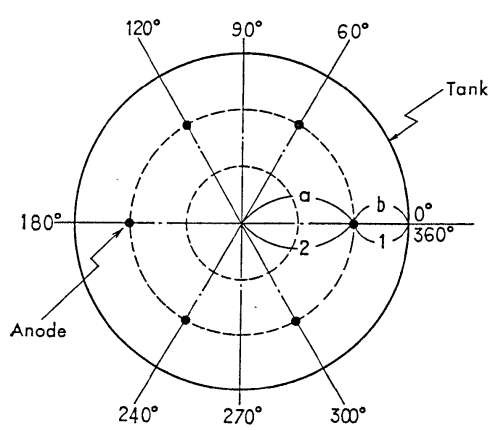

Fig. 9 Configuration of electrodes for the cathodic protection of a hot-water tank.

Number of line-anodes: 6

$$
a: b=2: 1
$$

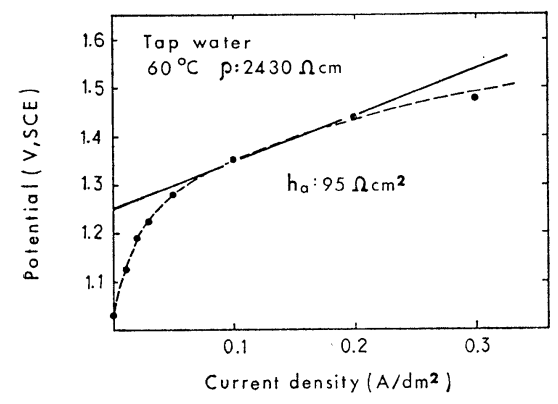

Fig. 10 Anodic polarization curve of Pt-Nb electrode in tap water.

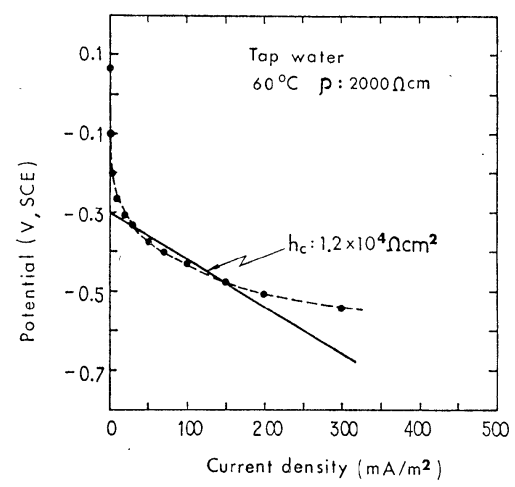

Fig. 11 Cathodic polarization curve of stainless steel in tap water.

なお， $\mathrm{Pt}-\mathrm{Ti}$ 電極の境界条件の設定に $\mathrm{Pt}-\mathrm{Nb}$ 電極の 分極曲線を用いたのは，本実験に打ける直線分極の適用 範囲では，Pt-Ti 電極と同様の分極挙動をとる ${ }^{10)}$ 之考兄

\section{ることができるためである。}

導電紙上への表現は，系の対称性から全体の $1 / 12$ を $1 / 5$ 縮尺で表示し，極間電圧として $1 \mathrm{~V}$ を印加した。

本実験の場合, アノードは $1 / 5$ 縮尺でも径が 0.3 $\mathrm{mm}, L_{a}=0.095 \mathrm{~mm}$ と非常に小さく, 導電紙上への正
Table 1 Parameters necessary for the estimation of potential/current distribution on the internal surface of a hot-water tank of stainless steel.

$\mathrm{E}^{\circ}$ : Free corrosion potential

h: Polarization resistance

L: Polarization parameter

\begin{tabular}{|c|c|c|c|}
\hline & $\begin{array}{c}\mathrm{E}^{\circ} \\
(\mathrm{V}, \mathrm{SCE})\end{array}$ & $\begin{array}{c}\mathrm{h} \\
\left(\Omega \mathrm{cm}^{2}\right)\end{array}$ & $\begin{array}{c}\mathrm{L} \\
(\mathrm{cm})\end{array}$ \\
\hline Aanode & 1.25 & 95 & 0.0475 \\
\hline Cathode & -0.3 & $1.2 \times 10^{4}$ & 6 \\
\hline
\end{tabular}

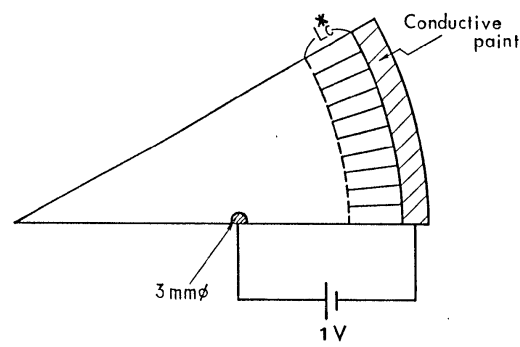

Fig. 12 Representation on the electroconductive paper of the model shown in Fig. 9.

確な表示は不可能であるため，アノード形状の表示では Fig. 12 に示すように，導電紙上に表示可能な電極とし て $3 \mathrm{~mm} \phi$ の電極を同心円として表示し, 電位/電流分 布の測定を行った。これは次のような考方方に基づいて いる。

微小円電極に招いては, その周团の等電位線は適当な 大きさのところまでは円電極の中心を中心とした同心円 状に描かれると考えることができる11)。この場合，切 断・合成則により等電位線を電極に置き換えたとする と, 同心円である二つの半円電極間の抵抗 $R_{3}$ は次式よ り求めることができる。

$$
R_{3}=\rho^{*} / \pi \ln \left(r / r_{0}\right)
$$

ここで $r, r_{0},\left(r>r_{0}\right)$ は，同心円である二つの円電極 の半径を示す。

(8) 式が成立すると考兄られる範囲内では，電極を実 際の形状より同心円状に大きく描くことによって測定を 行っても，得られたデータに対して (8) 式を用いて元の 形状の電極での值汇補正することは可能であるという考 えである。

Fig. 12 に扔いて, 導電紙上の極間抵抗 $R_{2}$ 及び抵抗 率 $\rho^{*}$ はそれぞれ，745 $\Omega, 437 \Omega$ であった。

また， $0.3 \mathrm{~mm} \phi$ の電極形状の表示が可能であったと すれば, $0.3 \mathrm{~mm} \phi$ の半円から $3 \mathrm{~mm} \phi$ の半円までの抵 抗值は, この範囲内で等電位線が電極形状と同心円状に 描かれるとの仮定のもとに (8) 式より $R_{3}=320 \Omega$ と求 

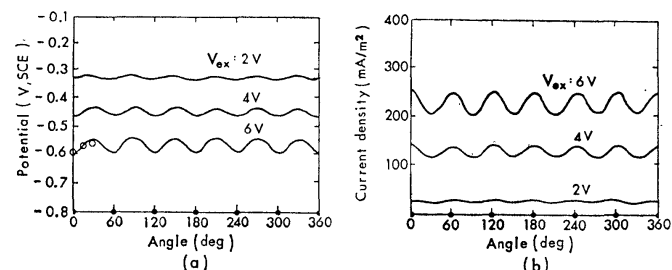

(b)
Fig. 13 Results for the cathodic protection of a tank as shown in Fig. 9 by electroconductive paper method.

Measured values in an actual system are indicated by open circles

(a) Potential distribution

(b) Current density distribution

Table 2 Estimated values of anode potential and current density on a Pt-Ti anode at given electrolysis voltage for electrode configuration of Fig. 9

Tank diameter: $1.5 \mathrm{~m}$

Anode diameter: $1.5 \mathrm{~mm}$

Resistibility of water: $2000 \Omega \cdot \mathrm{cm}$

\begin{tabular}{|c|c|c|}
\hline$V_{e x}(V)$ & $E_{a}(V, S C E)$ & $i_{a}\left(A / d^{2}\right)$ \\
\hline 2 & 1.28 & 0.04 \\
\hline 4 & 1.44 & 0.20 \\
\hline 6 & 1.59 & 0.36 \\
\hline
\end{tabular}

$V_{e x}$ : Electrolysis voltage

$E_{a}$ : Anode potential

$i_{a}$ : Current density

まる。

一方，分極パラメータ $L_{a}$ の取り扱いについては， (6)，(7) 式より $R_{1}$ 及び $\alpha$ (本系の場合， $R=R_{1}+R_{2}+$ $\left.R_{3}\right)$ を求めると, そ机ぞれ $88 \Omega, 0.076$ となるため, 本系では $L_{a}$ の存在も考慮することにした。

Fig. 12 に示す測定によって得られたデータは，極間 抵抗として $R_{2}$ のみを考慮した電位/電流分布を示す。 求めるものは， $R_{1}, R_{2}, R_{3}$ を考慮した電位/電流分布で ある。測定系に打いて， $R_{1}, R_{2}, R_{3}$ はシリーズに存在す るため, 極間抵抗として $\left(R_{1}+R_{2}+R_{3}\right)$ を考光, Fig. 12 の測定より得られたデータに対し， $R_{2} /\left(R_{1}+R_{2}+R_{3}\right)$ の 係数を乗ずることによって補正を行った。更に (4)，(5) 式によって，実環境に唎る電位/電流分布に換算した 結果を Fig. 13 に示す。電位分布カーブ中に示す○印 は, 極間電圧 $6 \mathrm{~V}$ で運転中の実機に和けるタンク電位 測定結果を示す。実機に抢汸る電位測定では, 電源の ON-OFF 瞬時における電位変化を IR ドロップとして
補正した。また，実測值との対応は確認することはでき なかったが導電紙法より推定される $\mathrm{Pt}-\mathrm{Ti}$ 電極の電位/ 電流密度を Table 2 に示した。電位分布に関して実測 值と導電紙結果との間にはよい対応が示されたが，他の 推定値に沶いても実系に㧤いて十分考兄られる対応性の ある值が得られた。導電紙法による電位/電流分布の推 定は，本系に执いても十分可能であると考学ることがで きる。

\section{4. まとめ}

電気防食系として，海洋に抢ける鋼矢板及びステンレ ス製温水タンク内面側壁を選び，導電紙による電位/電 流分布の推定結果と実測值との対応を調べた。

導電紙結果と実測値との間にはよい対応が得られた。

電気防食系に打いては，カソードに対して分極現象も 考慮した上でのラプラス方程式の解法が必要となる場合 が多い。導電紙法はこの種の問題に対して比較的容易に 解が得られるところに利点があるため, 電気防食系にお ける電位/電流分布の推定には非常に有効な手段である と考光ることができる。

\section{[謝 辞]}

本研究の遂行にあたり種々の御指導, 御批判をいただ いた東京大学生産技術研究所 増田正孝氏, 金属材料技 術研究所 小玉俊明氏, 藤井哲雄氏に感謝致します。

(Received April 26, 1984)

\section{文献}

1) C. Kasper: J. Elect. Chem. Soc., 77 (1940).

2) J. N. Ager, T. P. Hoar: Discussion of the Faraday Soc., 1, 162 (1974).

3) E. E. Nelson: Corrosion, 13, 315t $\sim 320 t$ (1957).

4) V. A. Pritula: "Cathodic Protection of Pipelines and Storage Tanks" Her Majesty's Stationery Office, London (1953).

5) J. H. Morgan: Corrosion, 15: 417t (1959).

6) 高橋正雄, 増子 昇:「工業電解の化学」, アグ ネ, (1979).

7) 増田正孝：第 10 回コロージョン・セミナー資 料, 腐食防食協会 (1983).

8）望月紀保：第 10 回コロージョン・セミナー資 料, 腐食防食協会 (1983).

9）運輸省港湾局監修：「港湾の施設の技術上の基 準, 同解説」, 日本港湾協会 (1979).

10）望月紀保：中川防蝕社内資料.

11）小玉俊明，藤井哲雄，馬場晴雄：防食技術， 33, 343 (1984). 